\title{
The effects of slope length and coverage ratio on nitrogen and phosphorus loss in red soil Regions of southern China
}

\author{
Qian Jing ${ }^{1,2}$, Zhang Liping ${ }^{3 *}$ \\ ${ }^{1}$ Anhui Jianzhu University, 230601 Hefei, China \\ ${ }^{2}$ Key Laboratory of Huizhou Architecture in Anhui Province, 230601 Hefei, China \\ ${ }^{3}$ Zhejiang Provincial Key Laboratory of Subtropical Soil and Plant Nutrition, Key Laboratory of Polluted Environment Remediation and \\ Ecological Health, Ministry of Education, College of Environmental and Resource Sciences, Zhejiang University, Hangzhou 310058 , P. \\ R. China.
}

\begin{abstract}
Soil nutrient loss not only reduces soil productivity, but also causes non-point source pollution and accelerates the eutrophication of surface water. In order to understand the effects of slope lengths $(2 \mathrm{~m}$, $4 \mathrm{~m})$, vegetation coverage ratios $(15 \%, 30 \%, 45 \%, 60 \%, 90 \%)$ on the mechanisms of soil nutrient loss, the research studied the simulated rainfall experiment with the slope gradient of $20^{\circ}$, the rainfall intensity of $2.0 \mathrm{~mm} / \mathrm{min}$ and the time of producing runoff for about $30 \mathrm{~min}$. The experimental results showed that the runoff coefficient is mainly affected by vegetation coverage ratio.
\end{abstract}

\section{Introduction}

Nitrogen $(\mathrm{N})$ and phosphorus $(\mathrm{P})$ are not only the required nutrients for the sustainable development of agroecosystem, but also identified as the main sources of non-point pollution because of their losses caused by surface runoff (Domburg P.,2000). Furthermore, in recent years, in pursuit of high-yields in agriculture, excessive amount of fertilizer was applied but had lower utilization ratio (Jiang et al., 2014), and resulted in serious water-body pollution. According to the investigation, the agricultural non-point source pollution accounts for $60-80 \%$ of the total amount of non-point pollution in China (Miao J., et al.,2010). As for the pollutants in the Lake Chaohu of China, $69.5 \%$ of total nitrogen (TN) and $51.7 \%$ of total phosphorus (TP) come from non-point pollution in 1995 alone (Luo et al.,2007). In the Lake Taihu of China, 40-90\% of total nitrogen (TN) and $38-90 \%$ of total phosphorus (TP) were from the discharge of the agricultural land (Guo et al.,2004).

In order to reduce the loss of $\mathrm{N}$ and $\mathrm{P}$ in the surface runoff to the water body and prevent the eutrophication of water body, a number of researches have been done about $\mathrm{N}$ and $\mathrm{P}$ losses of agricultural systems in the past decades. The concentration of $\mathrm{TN}(0.2-0.5 \mathrm{mg} / \mathrm{L})$ (Leungprasert et al.,2010) or the concentration of TP $(0.02-0.035 \mathrm{mg} / \mathrm{L})$ in water body can lead to eutrophication (Meng et al., 2017). The excessive amounts of $\mathrm{N}$ released not only caused the pollution of both groundwater and surface water but also released the greenhouse gas and thus led to the global warming. The load of P in surface runoff mainly came from the soil surface and desorption of suspended solids or sediment, and $\mathrm{P}$ was also the restraining factor of the eutrophication of inland water body and had low critical concentration. The concentration of $\mathrm{P}$ in runoff was correlated with the fertilizer amounts applied, the P cycle of plant-soil systems, the amounts of activated P, and the time interval between fertilizer applied and precipitation (Nacduff et al., 1984). Many researches indicated that $\mathrm{N}$ and $\mathrm{P}$ losses caused by surface runoff is mostly influenced by topography, vegetation coverage, precipitation (intensity and duration), tillage methods, and soil physicochemical properties, etc. Among these factors, improvement of fertilization patterns, tillage ways and reasonable amount of fertilization application can sufficiently reduce $\mathrm{N}$ and $\mathrm{P}$ losses (Wang et al.,2015).

Runoff from agricultural land was the main carrier of nutrient and eroded sediment. During the rainfall, interaction occurred among rain water, runoff and soil surface, to some extent, while vegetation coverage ratio affected rainfall intensity, protected soil surface from the direct impact of rainfall drops, reduced the sediment yield, and affected runoff to infiltrate into deep-layer soil. The growth of vegetation shoots and roots can improve soil physical properties around roots and prevent soil surface sealing, thus increase the infiltration rate (Gao et al., 2009).

Simulated rainfall experiments allow the control of the rainfall amount, rainfall intensity and rainfall duration, so these are suitable to study nutrient loss and soil erosion process (Meyer et al., 1994; Chen et al., 1991). The objectives of this study were: 1 ) to evaluate the effects of slope lengths and vegetation coverage ratios on surface runoff characteristics and sediment yield; 2) to investigate the effects of slope lengths and vegetation coverage ratios on the concentration of $\mathrm{N}$ and $\mathrm{P}$ loss in surface runoff.

* Corresponding author: L. P. Zhang. E-mail: lpzhang@zju.edu.cn 


\section{Materials and methods}

The simulated rainfall experiment was conducted in 3 plots. In each plot, two troughs were arranged with a slope gradient $20^{\circ}, 0.5 \mathrm{~m}$ in width, $0.5 \mathrm{~m}$ in depth and 2 $\mathrm{m}$ and $4 \mathrm{~m}$ in length, respectively. In each plot, two replicates were also produced. Chinese cabbage, 'Zhebai No.6', was planted in each trough. This type of Chinese cabbage was commonly planted in local vegetable fields.

The soil used in experiment was classified as a typical yellow-red loam collected from Lin'an in the west of Zhejiang province, representing the most common soil type in Zhejiang province. A variety of soil properties were measured for each plot. They are cited as follows: the content of clay, $25.84 \%$; silt $49.10 \%$; sand $25.05 \%$; $\mathrm{pH} 4.5$; soil density $1.12 \mathrm{~g} / \mathrm{cm} 3$; soil organic carbon $10.76 \mathrm{~g} / \mathrm{kg}$; TN $0.77 \mathrm{~g} / \mathrm{kg}$; and TP $0.21 \mathrm{~g} / \mathrm{kg}$ (Bao et al., 2000).

The six main experiment targets in surface runoff include: total nitrogen $(\mathrm{TN})$, nitrate nitrogen $\left(\mathrm{NO}_{3}{ }^{-}-\mathrm{N}\right)$, ammonia nitrogen $\left(\mathrm{NH}_{4}{ }^{+}-\mathrm{N}\right)$, total phosphorus (TP), total dissolved phosphorus (TDP), and particulate phosphorus (PP) (Bao, et al.,2000). $\mathrm{NO}_{3}{ }^{-}-\mathrm{N}, \mathrm{NH}_{4}{ }^{+}-\mathrm{N}$ and TDP in surface runoff were determined for samples filtered through $0.45 \mu \mathrm{m}$ filters, which was considered to be the soluble form. $\mathrm{NO}_{3}{ }^{-}-\mathrm{N}$ was measured by ultraviolet spectrophotometry, and $\mathrm{NH}_{4}^{+}-\mathrm{N}$ was analyzed by indophenol blue colorimetry. $\mathrm{TN}$ and $\mathrm{TP}$ were analyzed by using unfiltered samples; Alkaline potassium persulfate digestion was used to determine $\mathrm{TN}$ in surface runoff. TDP and TP were analyzed by Ammonium molybdate spectrophotometric method, and PP was determined by subtracting TDP from TP.

All statistical analyses were performed by using SPSS 18.0. Analysis of Correlation was assessed by Pearson's correlation coefficient (r) for all analyses, and a threshold of $\mathrm{p}<0.05$ was used to assess statistical significance.

The objectives of this study were: 1) to evaluate the effects of slope lengths and vegetation coverage ratios on surface runoff characteristics and sediment yield; 2) to investigate the effects of slope lengths and vegetation coverage ratios on the concentration of $\mathrm{N}$ and $\mathrm{P}$ loss in surface runoff.

\section{Results and discussion}

\subsection{Different slope lengths and different vegetation ratios on the characteristics of runoff and sediment}

Based on values of slope length, coverage ratio,runoff coefficient and sediment yield,the significance level of these factors was calculated using SPSS

The significance levels of each factor of sediment yield and runoff coefficient were given in Table 1. Table 1 showed that slope length had significant effects on sediment yield, but their extremely significant level was less than 0.01 . The significant level of the effects of the runoff coefficient on sediment yield was less than 0.05 . The runoff coefficient was mainly affected by slope lengths, vegetation coverage ratios, meanwhile, while runoff coefficient mainly affected sediment yield but their extremely significant level was less than 0.01 .

Based on the observation of experimental results, the infiltration rate of soil was affected not only by soil properties, but also the slope lengths and vegetation coverage ratios.

There are many literatures that pointed out that increasing vegetation coverage ratio could protect soil surface layer from the direct impact of raindrops and to some extent reduce water loss and soil erosion (Smets et al.,2008).Vegetation cover could mainly hold up a certain amount of the rainwater to soil surface layer and reduce the kinetic energy of raindrops. Then soil surface roughness caused by vegetation cover reduced surface flow of the runoff, increased the infiltration time, and thus put off the runoff-producing time, meanwhile, vegetation roots improved the soil infiltration capacity.

\subsection{The effect of slope lengths and vegetation ratios on the nitrogen and phosphorus concentrations in runoff}

The average concentration of $\mathrm{N}$ and $\mathrm{P}$ of 10 stimulated rainfall experiments obtained from the five different stages of vegetation cover ratios $(15 \%, 30 \%, 45 \%, 60 \%$, $90 \%$ ), different slope lengths $(2 \mathrm{~m}, 4 \mathrm{~m})$.

Slope length, vegetation coverage ratio were two important factors that affected nutrients loss. The slope length and vegetation coverage ratio affected the concentration of $\mathrm{N}$ and $\mathrm{P}$ in runoff by means of changing the volume of runoff and sediment yield. High vegetation cover ratio on the slope came into being simply because of the less amount and slow velocity of runoff, which made more soluble $\mathrm{N}$ and $\mathrm{P}$ in top soil dissolved into runoff.

As showed in Table 2. and Table 3, the concentration of $\mathrm{N}$ and $\mathrm{P}$ increased with the increasing of slope lengths. According to the analysis of correlation between slope length and loss concentration showed as: $\mathrm{TN}(\mathrm{P}>0.05)$, TP $(\mathrm{P}>0.05)$, the effects of slope length on the concentration of TN and TP were not obvious.

\section{Conclusion}

The present study took slope length, vegetation cover ratio and different fertilization treatments as variable factors, investigated the mechanism of these factors affected runoff volume, sediments yield and N, P loss:

1)There are significant correlation between vegetation coverage ratio, runoff coefficient and sediment yield $(\mathrm{P}<0.01)$ and runoff volume and sediment yield decrease with the increasing of vegetation coverage ratio. Sediment yield mainly depends on slope length, and the effects of different fertilizer treatments on runoff coefficient and sediment yield are not obvious.

2)According to the analysis of relationships between variable factors about $\mathrm{TN}$ and TP: slope length, vegetation coverage ratio, the results showed that the correlation coefficient of vegetation coverage ratio and TN concentration is slope lengths have no significant 
impact on the concentration change of the losses of both $\mathrm{TN}$ and TP $(\mathrm{P}>0.05)$.

\section{Figures and tables}

Table 1. Significance levels of factors under different slope length and coverage ratios

Table 2. Nitrogen loss in runoff from slope lengths.

Table 3. Phosphorus loss in runoff under different slope lengths

Table 1. Significance levels of factors under different slope length and coverage ratios

\begin{tabular}{cccccc}
\hline Y & SL (m) & $\begin{array}{l}\text { ROT } \\
(\mathrm{min})\end{array}$ & RC & $\begin{array}{c}\text { SY } \\
(\mathrm{g})\end{array}$ & $\begin{array}{c}\text { CR } \\
(\%)\end{array}$ \\
\hline SY $(\mathrm{g})$ & $<0.01$ & 0.01 & 0.05 & 1 & 0.54 \\
$\mathrm{RC}$ & $<0.01$ & 0.76 & 1 & $<0.01$ & 0.17 \\
\hline \multicolumn{5}{c}{ SL:Slope length;CR:Coverage ratio;SY: Sediment } \\
yield;;RC:Runoff coefficient; ROT:Runoff occurrence time
\end{tabular}

Table 2. Nitrogen loss in runoff from slope lengths

\begin{tabular}{ccccc}
\hline \multirow{N}{*}{$\begin{array}{c}\mathrm{N} \\
\text { concentrati }\end{array}$} & $\mathrm{SL}$ & $\mathrm{TN}$ & $\mathrm{NO}_{3}{ }^{-}-\mathrm{N}$ & $\mathrm{NH}_{4}{ }^{+}-\mathrm{N}$ \\
\cline { 2 - 5 } on $\left(\mathrm{mg} \mathrm{L}^{-1}\right)$ & $2 \mathrm{~m}$ & $2.9 \pm 0.5 \mathrm{c}$ & $1.57 \pm 0.7 \mathrm{c}$ & $0.32 \pm 0.14 \mathrm{c}$ \\
& $4 \mathrm{~m}$ & $3.4 \pm 0.7 \mathrm{c}$ & $2.06 \pm 0.4 \mathrm{c}$ & $0.46 \pm 0.27 \mathrm{c}$ \\
\hline
\end{tabular}

SL:Slope length;

Table 3. Phosphorus loss in runoff under different slope lengths

\begin{tabular}{ccccc}
\hline $\mathrm{P}$ & $\mathrm{SL}$ & $\mathrm{TP}$ & $\mathrm{TDP}$ & $\mathrm{PP}$ \\
\cline { 2 - 5 } $\begin{array}{c}\text { concentrati } \\
\text { on }\left(\mathrm{mg} \mathrm{L}^{-1}\right)\end{array}$ & $2 \mathrm{~m}$ & $0.68 \pm 0.3 \mathrm{c}$ & $0.17 \pm 0.3 \mathrm{c}$ & $0.55 \pm 0.3 \mathrm{c}$ \\
& $4 \mathrm{~m}$ & $0.72 \pm 0.4 \mathrm{c}$ & $0.19 \pm 0.4 \mathrm{c}$ & $0.56 \pm 0.2 \mathrm{c}$ \\
\hline
\end{tabular}

SL:Slope length;

\section{Acknowledgement}

Funding for this work was supported by the Introduction of talents and doctoral program of Anhui JianZhu University(2018QD13); the Science and Technology Major projects of Anhui Province (18030801106, 16030801118); the Key Research and Development Plan of Anhui Province, Granted (201904a07020070)

\section{References}

1. H.Y. Guo, X.R. Wang, J.G. Zhu, Environ. Geochem. Geochem hlth.(2004).

2. J.H. Jiang, J.Y. Zhang, H.Hu. J. Zhejiang Univ. (2014).

3. J. Miao, Z. Ren, J.P.Shi, EST.(2010).

4. J.H.nacduff,R.E.White.Plant soil.(1980).

5. J.Wang, A.G. Lu, X.S. Guo, Nutr. cycl.Agroecosys.(2015).

6. L.C. Luo, Q.Q. Bao, L.Y. Ying. Hydrobiologia. (2007).
7. P. Domburg,A.C. Edwards,A.H. Sinclair.J. SCI. FOOD AGR. (2000).

8. S.D .Bao, Soil and agro-chemistry analysis. third ed. Beijing: China Agriculture Press(2000).

9. S.Leungprasert, P. Chanakul. Int. J. Environ. Res.(2010).

10. T.Smerts,J.Poesen,E.Bochet,Prog.Phys.Geos.(2008).

11. X.S. Meng, W.B.Zhang,L.Gao,RES. (2017).

12. Y. Gao, B. Zhu, P. Zhou, Nutr. cycl.Agroecosys. (2006). 